\title{
The Effect of COVID-19 Pandemic on the Infants' Microbiota and the Probability of Development of Allergic and Autoimmune Diseases
}

\author{
Saba Ebrahimi ${ }^{a}$ Saghi Khatami ${ }^{a}$ Mehrnaz Mesdaghia, b, c \\ aDepartment of Immunology, School of Medicine, Shahid Beheshti University of Medical Sciences, Tehran, Iran; \\ ${ }^{b}$ Department of Allergy and Clinical Immunology, Mofid Children's Hospital, Shahid Beheshti University of \\ Medical Sciences, Tehran, Iran; 'CClinical Research Developement Center, Mofid Children's Hospital, Shahid Beheshti \\ University of Medical Sciences, Tehran, Iran
}

\section{Keywords}

Gut microbiota $\cdot$ Neonates · Microbiome · Allergy ·

Autoimmunity

\begin{abstract}
The human microbiota plays a significant role in various mechanisms of the body. The formation of a healthy microbiota, especially in early childhood, has a significant effect on maintaining human health. Since the onset of coronavirus disease 2019 (COVID-19), the disease has caused many changes in human life. According to the available information, many of these factors affect the composition and diversity of the body's microbiota, so this pandemic may alter and disrupt the microbiota and consequently increase the incidence of other diseases such as allergic and autoimmune disorders, especially in children and infants born in this era. In this review, the probable impact of the COVID-19 pandemic on body's microbiota and its relationship with the emergence of future diseases is discussed.
\end{abstract}

(c) 2021 S. Karger AG, Basel

Saba Ebrahimi and Saghi Khatami are co-first authors.

Edited by: H.-U. Simon, Bern.

\section{Introduction}

Since the onset of coronavirus disease 2019 (COVID-19) epidemic and its spread around the world, this disease has had a significant impact on various aspects of the life of individuals and communities and has caused changes in lifestyle, social interactions, eating habits, etc. "Microbiota" refers to microorganisms that live in various parts of the human body such as the skin, mouth, respiratory system, and gastrointestinal tract $[1,2]$, which weighs about $1.5 \mathrm{~kg}$ and is composed of $>100$ trillion microorganisms $[2,3]$. It has been found that the most important time of exposure to environmental microbial species and nonharmful commensal microbes is during pregnancy, childbirth, and the first months of infancy [4, 5]. Numerous factors such as delivery mode, nutrition, lifestyle, and living environment affect the composition and diversity of microbiota in children [6]; therefore, lifestyle changes caused by the COVID-19 pandemic can also change the microbiota (shown in Fig. 1). Interactions between the human body and microbiota are extensive and include the regulation of immune responses [7], maintenance of safe intestinal homeostasis, and disease modification [8]. Microbial colonization at the beginning of life

Correspondence to:

Mehrnaz Mesdaghi, m.mesdaghi@ sbmu.ac.ir 


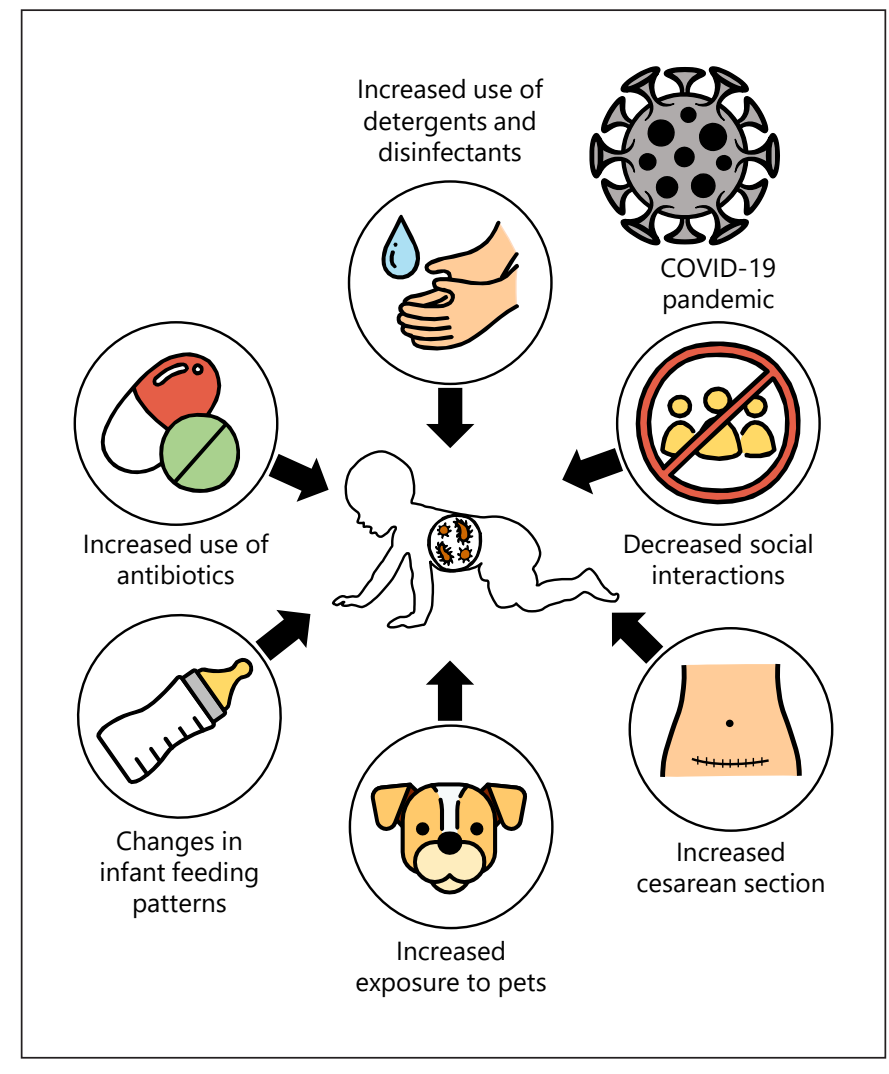

Fig. 1. Different factors affecting the formation of microbiota in neonates during COVID-19 pandemic.

plays an essential role in the development of innate and acquired immune systems $[9,10]$. The formation of healthy gut microbiota leads to T helper type 1 (Th1) cells dominance in Th1/Th2 balance [11], while a change in the homeostasis of the host microbiota can shift the Th1/ Th2 cytokines balance toward the Th2 responses [12]. Numerous studies have shown the relationship between the composition and diversity of gut microbiota and its effect on the incidence of allergic diseases in infants and children [13-15]. Cytokines produced by Th2 cells, especially interleukin 4 (IL-4) and IL-5, are associated with many allergic diseases such as asthma and allergic rhinitis, and IL- 4 is the major cytokine that increases IgE production [16]. In addition, many autoimmune diseases have been associated with alterations in the composition and diversity of the body's microbiota [17-19]. Since changes in the body's microbial composition may lead to loss of immune tolerance, the human microbiome appears to play a key role in the development of autoimmune diseases $[20,21]$. If tolerance mechanisms are not completely effective, microorganisms can elicit immune responses against the host body [22-24]. In this review, we investigate the effects of the COVID-19 pandemic on the microbiota of pregnant women and their infants and the possibility of increasing the incidence of allergic and autoimmune diseases in children born during the $\mathrm{CO}$ VID-19 pandemic.

\section{The Effect of COVID-19 Pandemic on Mode of Delivery}

The time and mode of delivery are important and influential factors in the composition of gut microbiota [25]. Cesarean section is increasing worldwide $[26,27]$, but it has several complications for both mother and child [27, 28]. The rate of cesarean section in women infected with COVID-19 is even higher than the general population [29]. In a study of 108 pregnant women with COVID-19, cesarean section accounted for $92 \%$ of all deliveries, and only $8 \%$ of participants in this study had vaginal deliveries [30]. In another study, all pregnant patients with COVID-19 pneumonia were delivered by cesarean section [31]. Among the reasons for cesarean section in women with COVID-19 were worsening of the mother's condition, severe preeclampsia, history of cesarean delivery, and fetal distress $[31,32]$. In addition, concern about the risk of mother-to-child virus transmission during vaginal delivery has been another reason for cesarean section [32]. It has been observed that in infants, who are born by cesarean section (instead of vaginal delivery and crossing the birth canal, i.e., colonized with the maternal microbiota), the gut microbiota is formed with delay, and its colonization has a pattern similar to that of the mother's skin [25] (shown in Fig. 2). The study of the effect of this difference in microbiome on the incidence of allergic diseases has shown that cesarean delivery reduces microbial diversity and reduces Th1-cell responses in the early years of life [33]. Also, several research studies have linked cesarean section to the development of asthma, eczema, and allergic rhinitis [34-36]. Furthermore, some studies have shown the effect of cesarean section on increasing the risk of autoimmune diseases in children. According to a study by Sevelsted et al. [37], the cesarean section was associated with a significant increase in the risk of asthma, juvenile arthritis, and inflammatory bowel disease in children. Another study found that children born by cesarean delivery, especially the elective ones (which has been done at mothers' request, probably due to her fear of childbirth), were at higher risk for diseases related to immune dysfunction [38]. The pandemic has also affected the early days after delivery. The birth of a new baby in a family is usually accompanied by family and friends celebrating the event, but during the COVID-19 pandemic, gatherings and cel- 
ebrations are strictly limited. In small gatherings, the guests are asked to use a mask, wash their hands, and maintain a distance of about $2 \mathrm{~m}$ with the neonate [39]. It has been observed that social relationships are associated with diversity in fecal microbiota [40]. Therefore, reducing family and friendly gatherings during the pandemic can also alter the baby's microbiome.

\section{COVID-19 and Infants' Feeding Pattern}

In addition to the mode of delivery, the infant's feeding pattern plays an important role in the formation of microbiota in the first year after birth [41]. Microbiota is transmitted through nonsterile breast milk [42], and breastfeeding has an important influence on the gut microbiome compared to formula feeding [43]. The mucosal immune system, in which gut microbiota are involved, suppresses immune responses to nonharmful ingested antigens [44]. Diseases caused by a deficiency in the immune system have been observed to be less common in breastfed infants [45]. The results of a study by Cardwell et al. [46] showed that breastfeeding for $>3$ months, or exclusively for $>2$ weeks after birth, is related with a 15$30 \%$ decrease in the risk of developing type 1 diabetes in children. Another study found that exclusive breastfeeding for $>2$ weeks is associated with a reduction in the risk of type 2 diabetes in the future life [47]. Other studies have examined the association between breastfeeding and other autoimmune diseases. The results of a study showed that breastfeeding, regardless of its duration, reduces the risk of rheumatoid arthritis [48]. Another study found that among HLA-DR4-negative infants, those who had a positive rheumatoid factor were less likely to be breastfed for $>3$ months compared to infants whose rheumatoid factor was negative [49]. Some studies have also shown an association between breastfeeding and a reduced risk of multiple sclerosis $[50,51]$. In addition, according to the results of a meta-analysis, the risk of developing celiac disease was significantly lower in infants who were breastfed at the time of gluten intake compared with those who were not breastfed [52].

Based on the available documents, there has been no evidence of severe acute respiratory syndrome coronavirus 2 (SARS-CoV-2) in the breast milk of mothers suspected to or with COVID-19 and its transmission to the infant through breastfeeding $[53,54]$. Therefore, it is recommended that suspicious mothers, and even those infected with SARS-CoV-2, continue breastfeeding [55]. However, these mothers should use a mask while breastfeeding, wash their hands with soap before touching the baby, and/or use alcohol-based disinfectants [55].

The Effect of COVID-19 Pandemic on Infant's Microbiota

\section{COVID-19 and the Use of Detergents}

Exposure to chemicals in detergents has been shown to have a significant effect on the composition and function of microbiota [56]. The metabolic activity of gut bacteria plays a vital role in the human body [57]. In one study, fecal diversity and concentration of metabolites including short-chain fatty acids (SCFAs) derived from microbiota were significantly reduced by the use of dishwashing detergents [58]. The results of a study showed that the prevalence of atopy was lower in children who had higher levels of SCFAs in their feces at the age of 1 year. In addition, these children were less likely to develop asthma and be diagnosed with allergic rhinitis and food allergies [59]. The gastrointestinal tract can communicate with the brain through metabolites produced by commensal bacteria such as SCFAs $[60,61]$. In patients with multiple sclerosis, a significant reduction in the percentage of bacteria producing SCFAs has been observed [18]. Also, the presence of SCFA-producing bacteria has been shown to maintain intestinal integrity by inducing the production of appropriate amounts of mucin [62], and changes in the production of SCFAs are associated with type 1 diabetes [62, 63]. Therefore, increased usage of detergents and hand sanitizers to protect infants during the pandemic may increase the incidence of allergic and autoimmune diseases in children (summarized in Fig. 2). Many factors limit breastfeeding including the severity of the mother's illness, misconceptions by the medical team and parents about the safety of breastfeeding, hospital policy about mother and infant rooming-in after delivery, and maternal quarantine after discharge. Some mothers with COVID-19 are unable to breastfeed their infants due to the worsening of the disease, for whom, the use of pumped breast milk is recommended [55]; however, the available evidence has shown that how to breastfeed the baby (directly from the breast vs. the use of pumped breast milk) has a significant effect on the microbiota composition of milk and that indirect breastfeeding is associated with reduced milk richness and bacterial diversity $[64,65]$. Bifidobacterium and Lactobacillus are the most important probiotics in breast milk [66]. Many studies have shown the reduction of atopic eczema, one of the most common types of allergies in children, after the use of probiotics [67-69]. Evidence suggests that the use of pumped breast milk reduces milk Bifidobacteria [64]. Also, antibiotic treatment and cesarean section were associated with a decreased amount of Bifidobacterium and Lactobacillus in the infant's microbiota $[25,70]$ (summarized in Fig. 2). In addition, a decrease in colonization with Bifidobacteria in the first year of life has been observed to be associated with allergies in children $[71,72]$.

Int Arch Allergy Immunol 2022;183:435-442 437 


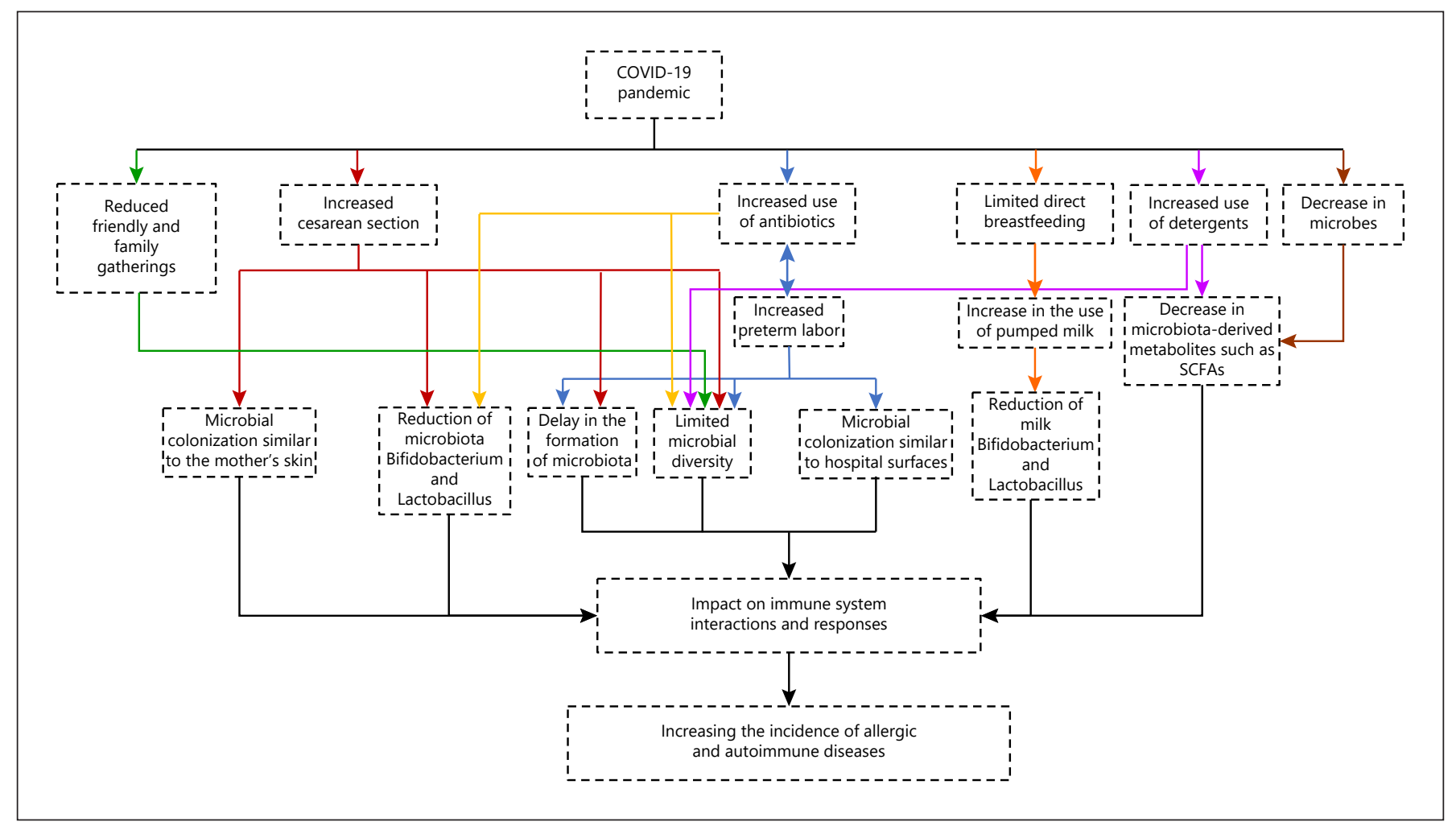

Fig. 2. The effect of changes caused by COVID-19 pandemic on the microbiota composition and diversity.

\section{Preterm Delivery and Antibiotic Treatment}

According to studies, up to $47 \%$ of COVID-19-infected hospitalized patients give birth prematurely [73-75]. In one article, inflammation has been reported as one of the most important factors in the occurrence of preterm labor [76]. Although bacterial infections often cause the onset of inflammatory cascades and preterm labor, antibiotic use in the absence of bacterial infections has been associated with the production of inflammatory cytokines and cause cytokine storms [76]. Therefore, antibiotic treatment should not be performed by default for pregnant women with COVID-19 and can only be prescribed if necessary and after confirmation of bacterial infection in these patients [77]. However, some available evidence suggests that many pregnant patients with severe COVID-19 have taken antibiotics, although no evidence of bacterial infection has been reported $[78,79]$. According to studies, maternal antibiotic treatment during and even before pregnancy has been associated with the abnormal establishment of gut microbiota in preterm infants $[80,81]$. Compared to term neonates, intestinal microbial colonization of preterm infants has been found to be delayed and has limited microbial diversity [82] (summarized in Fig. 2). In preterm infants, the composition of primary gut microbiota is similar to the bacterial composition of hospital surfaces [83]. In addition, the amount of potentially pathogenic bacteria in these infants is increased, and the amount of essential commensal bacteria is decreased $[84,85]$. Premature or low birth weight infants are at the highest risk for antibiotic-related disorders because they typically receive antibiotic treatment at birth to protect them from bacterial infections and earlyonset sepsis [86-88]. Antibiotic use has destructive effects such as reducing the bacterial diversity of the gut microbiota of these infants [88]. Disruption of the formation of gut microbiota by antibiotic administration may also affect the interaction with the immune system. In fact, taking antibiotics during pregnancy and after birth increases the risk of future illnesses such as asthma and other allergic diseases $[89,90]$. Only a few studies have looked into the impact of preterm delivery on the microbiota of breast milk. According to these studies, the bacterial composition found in the milk of mothers, who gave birth prematurely, was different from that found in the mature milk of the same mothers, and the frequency of bacteria in premature milk was lower [91]. Monocytes transmit bacteria 
from the intestine to the mesenteric lymph nodes and mammary glands via the entero-mammary pathway, which occurs in late pregnancy [92]. Therefore, this pathway may be insufficient in preterm labor and can lead to a decrease in the abundance of bacteria in breast milk.

\section{Contact with Pets during the COVID-19 Pandemic}

Numerous studies have shown that infants' contact with pets at the beginning of life and maternal contact with animals during pregnancy have a significant effect on the formation of gut microbiota in the child and can affect the incidence of atopic diseases [93-95]. In their study, Azad et al. [96] found that living with pets increased the richness and diversity of infants' gut microbiota. Another study has shown that increasing the number of pets in a child's environment in the first year of life is associated with a decrease in the prevalence of allergic diseases such as asthma and eczema at school age [97]. Due to factors such as quarantine and teleworking, keeping pets at home has increased significantly during the COVID-19 pandemic [98]. This may be in favor of preserving the diversity of microbiota and reducing the incidence of allergic and autoimmune diseases in children born during this period. However, although the available evidence suggests that the risk of animal to human transmission of COVID-19 is low [99], some pet owners abandoned their animals for the fear of transmitting SARSCoV-2. Also, a number of people were not able to take care of their pets due to job losses and financial problems happened during the pandemic [100].

\section{Conclusion}

From the beginning of the COVID-19 pandemic, the disease has had a significant impact on human health and lifestyle. Evidence has shown that one of the important effects of this pandemic is to alter the body's microbiota and increase the risk of dysbiosis, and since pregnancy and early infancy are critical times for microbiota formation, pregnant women and their infants are significantly affected by the condition. As numerous studies have confirmed the essential role of healthy human microbiota in regulating immune responses and maintaining body health, the changes and dysbiosis caused by the COVID-19 outbreak could increase the incidence of various disorders in the future, including allergic and autoimmune diseases, especially in children. However, due to the persistence of this pandemic and its unknown long-term effects, at the moment, the exact impact of this condition on children born during COVID-19 pandemic cannot be foreseen and needs to be clarified in future epidemiologic studies.

Based on our current knowledge about the low risk of SARS-CoV-2 transmission from pets and surfaces and the importance of proper formation of microbiota, increased infants' exposure to pets and decreased usage of disinfectants can be helpful in reducing the risk of future diseases. Moreover, mass vaccination will hopefully help returning to normal life, and having normal minimal social interactions could be the most important step toward normal formation of microbiota and immune responses.

\section{Conflict of Interest Statement}

The authors have no conflicts of interest to declare.

\section{Funding Sources}

The authors have no funding sources to declare.

\section{Author Contributions}

Mehrnaz Mesdaghi contributed to conception of the work, critical revision of the manuscript, and final approval of the manuscript. Saba Ebrahimi contributed to search of articles and data gathering, drafting of the manuscript, and final approval of the manuscript. Saghi Khatami contributed to search of articles and data gathering, drafting of the manuscript, and final approval of the manuscript.

\section{References}

1 Quigley EM. Basic definitions and concepts: organization of the gut microbiome. Gastroenterol Clin North Am. 2017 Mar;46(1):1-8.

2 Sender R, Fuchs S, Milo R. Revised estimates for the number of human and bacteria cells in the body. PLoS Biol. 2016 Aug 19;14(8): e1002533.
3 Pascale A, Marchesi N, Marelli C, Coppola A, Luzi L, Govoni S, et al. Microbiota and metabolic diseases. Endocrine. 2018;61(3):357-71.

4 Meropol SB, Edwards A. Development of the infant intestinal microbiome: a bird's eye view of a complex process. Birth Defects Res C Embryo Today. 2015;105(4):228-39.
5 Aagaard K, Ma J, Antony KM, Ganu R, Petrosino J, Versalovic J. The placenta harbors a unique microbiome. Sci Transl Med. 2014 May 21;6(237):237ra65.

6 Prince BT, Mandel MJ, Nadeau K, Singh AM. Gut microbiome and the development of food allergy and allergic disease. Pediatr Clin North Am. 2015;62(6):1479-92.
The Effect of COVID-19 Pandemic on Infant's Microbiota
Int Arch Allergy Immunol 2022;183:435-442 DOI: $10.1159 / 000520510$ 
7 Negi S, Das DK, Pahari S, Nadeem S, Agrewala JN. Potential role of gut microbiota in induction and regulation of innate immune memory. Front Immunol. 2019 Oct; 10: 2441.

8 Derrien M, van Hylckama Vlieg JE. Fate, activity, and impact of ingested bacteria within the human gut microbiota. Trends Microbiol. 2015;23(6):354-66.

9 Yatsunenko T, Rey FE, Manary MJ, Trehan I, Dominguez-Bello MG, Contreras M, et al. Human gut microbiome viewed across age and geography. Nature. 2012;486(7402):2227.

10 Fieten KB, Totté JEE, Levin E, Reyman M, Meijer Y, Knulst A, et al. Fecal microbiome and food allergy in pediatric atopic dermatitis: a cross-sectional pilot study. Int Arch Allergy Immunol. 2018 Feb 1;175(1-2):77-84.

11 Tulic MK, Hodder M, Forsberg A, McCarthy S, Richman T, DVaz N, et al. Differences in innate immune function between allergic and nonallergic children: new insights into immune ontogeny. J Allergy Clin Immunol. 2011;127(2):470-478.e1.

12 Mazmanian SK, Liu CH, Tzianabos AO, Kasper DL. An immunomodulatory molecule of symbiotic bacteria directs maturation of the host immune system. Cell. 2005 Jul 15; 122(1):107-18.

13 Ege MJ, Mayer M, Normand A-C, Genuneit J, Cookson WOCM, Braun-Fahrländer C, et al. Exposure to environmental microorganisms and childhood asthma. N Engl J Med. 2011 Feb 24;364(8):701-9.

14 Abrahamsson TR, Jakobsson HE, Andersson AF, Björkstén B, Engstrand L, Jenmalm MC. Low diversity of the gut microbiota in infants with atopic eczema. J Allergy Clin Immunol. 2012;129(2):434-40, 440.e1-2.

15 Watts AM, West NP, Zhang P, Smith PK, Cripps AW, Cox AJ. The gut microbiome of adults with allergic rhinitis is characterised by reduced diversity and an altered abundance of key microbial taxa compared to controls. Int Arch Allergy Immunol. 2021 Jan 1;182(2):94105.

16 Deo SS, Mistry KJ, Kakade AM, Niphadkar $\mathrm{PV}$. Role played by Th2 type cytokines in IgE mediated allergy and asthma. Lung India. 2010 Apr 1;27(2):66-71.

17 Vaahtovuo J, Munukka E, Korkeamäki M, Luukkainen R, Toivanen P. Fecal microbiota in early rheumatoid arthritis. J Rheumatol. 2008;35(8):1500-5.

18 Miyake S, Kim S, Suda W, Oshima K, Nakamura M, Matsuoka T, et al. Dysbiosis in the gut microbiota of patients with multiple sclerosis, with a striking depletion of species belonging to clostridia XIVa and IV clusters. PLoS One. 2015 Sep 14;10(9):e0137429.

19 Frank DN, St Amand AL, Feldman RA, Boedeker EC, Harpaz N, Pace NR. Molecularphylogenetic characterization of microbial community imbalances in human inflammatory bowel diseases. Proc Natl Acad Sci U S A. 2007;104(34):13780-5.
20 Belkaid Y, Hand TW. Role of the microbiota in immunity and inflammation. Cell. 2014; 157(1):121-41.

21 Shamriz O, Mizrahi H, Werbner M, Shoenfeld Y, Avni O, Koren O. Microbiota at the crossroads of autoimmunity. Autoimmun Rev. 2016;15(9):859-69.

22 Guilherme L, Kalil J, Cunningham M. Molecular mimicry in the autoimmune pathogenesis of rheumatic heart disease. Autoimmunity. 2006;39(1):31-9.

23 Getts DR, Chastain EM, Terry RL, Miller SD. Virus infection, antiviral immunity, and autoimmunity. Immunol Rev. 2013;255(1): 197-209.

24 Vojdani A, Pollard KM, Campbell AW. Environmental triggers and autoimmunity. Autoimmune Dis. 2014;2014:798029.

25 Dominguez-Bello MG, Costello EK, Contreras M, Magris M, Hidalgo G, Fierer N, et al. Delivery mode shapes the acquisition and structure of the initial microbiota across multiple body habitats in newborns. Proc Natl Acad Sci U S A. 2010 Jun 29;107(26):11971-5.

26 Da Silva Charvalho P, Hansson Bittár M, Vladic Stjernholm Y. Indications for increase in caesarean delivery. Reprod Health. 2019 May 30;16(1):72.

27 Rafiei M, Ghare Naz MS, Akbari M, Kiani F, Sayehmiri F, Sayehmiri K, et al. Prevalence, causes, and complications of cesarean delivery in Iran: a systematic review and metaanalysis. Int J Reprod Biomed. 2018 Jan 1; 16(4):221-34

28 Rosa F, Perugin G, Schettini D, Romano N, Romeo S, Podestà R, et al. Imaging findings of cesarean delivery complications: cesarean scar disease and much more. Insights Imaging. 2019 Sep 23;10(1):98.

29 Giaxi P, Maniatelli E, Vivilaki V. Evaluation of mode of delivery in pregnant women infected with COVID-19. Eur J Midwifery. 2020 Jul 2;4:28.

30 Zaigham M, Andersson O. Maternal and perinatal outcomes with COVID-19: a systematic review of 108 pregnancies. Acta Obstet Gynecol Scand. 2020;99(7):823-9.

31 Chen H, Guo J, Wang C, Luo F, Yu X, Zhang $\mathrm{W}$, et al. Clinical characteristics and intrauterine vertical transmission potential of $\mathrm{CO}$ VID-19 infection in nine pregnant women: a retrospective review of medical records. Lancet. 2020 Mar 7:395(10226):809-15.

32 Ashokka B, Loh MH, Tan CH, Su LL, Young $\mathrm{BE}$, Lye DC, et al. Care of the pregnant woman with coronavirus disease 2019 in labor and delivery: anesthesia, emergency cesarean delivery, differential diagnosis in the acutely ill parturient, care of the newborn, and protection of the healthcare personnel. Am J Obstet Gynecol. 2020;223(1):66-74.e3.

33 Jakobsson HE, Abrahamsson TR, Jenmalm MC, Harris K, Quince C, Jernberg C, et al. Decreased gut microbiota diversity, delayed bacteroidetes colonisation and reduced Th1 responses in infants delivered by Caesarean section. Gut. 2014;63(4):559-66.
34 Renz-Polster H, David MR, Buist AS, Vollmer WM, O'Connor EA, Frazier EA, et al. Caesarean section delivery and the risk of allergic disorders in childhood. Clin Exp Allergy. 2005;35(11):1466-72.

35 Thavagnanam S, Fleming J, Bromley A, Shields MD, Cardwell CR. A meta-analysis of the association between caesarean section and childhood asthma. Clin Exp Allergy. 2008 Apr;38(4):629-33.

36 Van Nimwegen FA, Penders J, Stobberingh EE, Postma DS, Koppelman GH, Kerkhof M, et al. Mode and place of delivery, gastrointestinal microbiota, and their influence on asthma and atopy. J Allergy Clin Immunol. 2011 Nov; 128(5):948-55.e1-3.

37 Sevelsted A, Stokholm J, Bønnelykke K, Bisgaard $\mathrm{H}$. Cesarean section and chronic immune disorders. Pediatrics. 2015 Jan 1;135(1): e92-8.

38 Kristensen K, Henriksen L. Cesarean section and disease associated with immune function. J Allergy Clin Immunol. 2016;137(2): 587-90.

39 CDC. Breastfeeding and caring for newborns: CDC; 2021 Jun 18. Available from: https: //www.cdc.gov/coronavirus/2019ncov/need-extra-precautions/pregnancybreastfeeding.html? CD C_A A refVal=https $\% 3 \mathrm{~A} \% 2 \mathrm{~F} \% 2 \mathrm{Fwww} . \mathrm{cdc}$. gov\% 2 F coron avirus\%2 F 2019 . ncov\%2Fprepare\%2Fpregnancy-breastfeeding.html.

40 Dill-McFarland KA, Tang ZZ, Kemis JH, Kerby RL, Chen G, Palloni A, et al. Close social relationships correlate with human gut microbiota composition. Sci Rep. 2019 Jan 24; 9(1):703.

41 Bäckhed F, Roswall J, Peng Y, Feng Q, Jia H, Kovatcheva-Datchary P, et al. Dynamics and stabilization of the human gut microbiome during the first year of life. Cell Host Microbe. 2015 May 13;17(5):690-703.

42 Jost $\mathrm{T}$, Lacroix C, Braegger CP, Rochat $\mathrm{F}$, Chassard C. Vertical mother-neonate transfer of maternal gut bacteria via breastfeeding. Environ Microbiol. 2014;16(9):2891-904.

43 Penders J, Gerhold K, Stobberingh EE, Thijs C, Zimmermann K, Lau S, et al. Establishment of the intestinal microbiota and its role for atopic dermatitis in early childhood. J Allergy Clin Immunol. 2013 Sep;132(3):601-7. e8.

44 Peters RL, Dang TD, Allen KJ. Specific oral tolerance induction in childhood. Pediatr Allergy Immunol. 2016;27(8):784-94.

45 Holmberg H, Wahlberg J, Vaarala O, Ludvigsson J. Short duration of breast-feeding as a risk-factor for beta-cell autoantibodies in 5 -year-old children from the general population. Br J Nutr. 2007;97(1):111-6.

46 Cardwell CR, Stene LC, Ludvigsson J, Rosenbauer J, Cinek O, Svensson J, et al. Breastfeeding and childhood-onset type 1 diabetes: a pooled analysis of individual participant data from 43 observational studies. Diabetes Care. 2012;35(11):2215-25. 
47 Owen CG, Martin RM, Whincup PH, Davey Smith G, Cook DG. Does breastfeeding influence risk of type 2 diabetes in later life? A quantitative analysis of published evidence. Am J Clin Nutr. 2006 Nov;84(5):1043-54.

48 Chen $\mathrm{H}$, Wang J, Zhou W, Yin $\mathrm{H}$, Wang $\mathrm{M}$. Breastfeeding and risk of rheumatoid arthritis: a systematic review and metaanalysis. J Rheumatol. 2015;42(9):1563-9.

49 Young KA, Parrish LA, Zerbe GO, Rewers M, Deane KD, Holers VM, et al. Perinatal and early childhood risk factors associated with rheumatoid factor positivity in a healthy paediatric population. Ann Rheum Dis. 2007; 66(2):179-83.

50 Conradi S, Malzahn U, Paul F, Quill S, Harms $\mathrm{L}$, Then Bergh F, et al. Breastfeeding is associated with lower risk for multiple sclerosis. Mult Scler J. 2013;19(5):553-8.

51 Ragnedda G, Leoni S, Parpinel M, Casetta I, Riise T, Myhr KM, et al. Reduced duration of breastfeeding is associated with a higher risk of multiple sclerosis in both Italian and Norwegian adult males: the EnvIMS study. J Neurol. 2015;262(5):1271-7.

52 Akobeng AK, Ramanan AV, Buchan I, Heller RF. Effect of breast feeding on risk of coeliac disease: a systematic review and meta-analysis of observational studies. Arch Dis Child. 2006;91(1):39-43.

53 Heydarpoor Z, Valizadeh L. Breastfeeding and COVID-19. Bull Acad Natl Med. 2020 Dec 1;23(5):646-53.

54 Salvatori G, De Rose DU, Concato C, Alario D, Olivini N, Dotta A, et al. Managing COVID-19-positive maternal-infant dyads: an Italian experience. Breastfeed Med. 2020; 15(5):347-8.

55 WHO Frequently Asked Questions. WHO Frequently Asked Questions : Breastfeeding and COVID-19 For health care workers. J Hum Lact. 2020;36(3):392-6.

56 Yee AL, Gilbert JA. MICROBIOME. Is triclosan harming your microbiome? Science. 2016;353(6297):348-9.

57 Thompson-Chagoyan OC, Fallani M, Maldonado J, Vieites JM, Khanna S, Edwards C, et al. Faecal microbiota and short-chain fatty acid levels in faeces from infants with cow's milk protein allergy. Int Arch Allergy Immunol. 2011 Oct;156(3):325-32.

58 Gerasimidis K, Bryden K, Chen X, Papachristou E, Verney A, Roig M, et al. The impact of food additives, artificial sweeteners and domestic hygiene products on the human gut microbiome and its fibre fermentation capacity. Eur J Nutr. 2020;59(7):3213-30.

59 Roduit C, Frei R, Ferstl R, Loeliger S, Westermann P, Rhyner C, et al. High levels of butyrate and propionate in early life are associated with protection against atopy. Allergy Eur J Allergy Clin Immunol. 2019;74(4):799-809.

60 Wang HX, Wang YP. Gut microbiota-brain axis. Chin Med J. 2016;129(19):2373-80.

61 Mayer EA, Tillisch K, Gupta A. Gut/brain axis and the microbiota. J Clin Invest. 2015;125(3): 926-38.
62 Brown CT, Davis-Richardson AG, Giongo A, Gano KA, Crabb DB, Mukherjee N, et al. Gut microbiome metagenomics analysis suggests a functional model for the development of autoimmunity for type 1 diabetes. PLoS One. 2011 Oct 17;6(10):25792.

63 Endesfelder D, Engel M, Davis-Richardson AG, Ardissone AN, Achenbach P, Hummel S, et al. Towards a functional hypothesis relating anti-islet cell autoimmunity to the dietary impact on microbial communities and butyrate production. Microbiome. 2016 Apr 26;4:17.

64 Moossavi S, Sepehri S, Robertson B, Bode L, Goruk S, Field CJ, et al. Composition and variation of the human milk microbiota are influenced by maternal and early-life factors. Cell Host Microbe. 2019 Feb 13;25(2):324-35. e4.

65 Moossavi S, Azad MB. Origins of human milk microbiota: new evidence and arising questions. Gut Microbes. 2020;12(1):1667722.

66 Fernández L, Langa S, Martín V, Jiménez E, Martín R, Rodríguez JM. The microbiota of human milk in healthy women. Cell Mol Biol. 2013;59(1):31-42.

67 Kukkonen K, Savilahti E, Haahtela T, Juntunen-Backman K, Korpela R, Poussa T, et al. Probiotics and prebiotic galacto-oligosaccharides in the prevention of allergic diseases: a randomized, double-blind, placebo-controlled trial. J Allergy Clin Immunol. 2007; 119(1):192-8

68 Kalliomäki M, Salminen S, Arvilommi H, Kero P, Koskinen P, Isolauri E. Probiotics in primary prevention of atopic disease: a randomised placebo-controlled trial. Lancet. 2001;357(9262):1076-9.

69 Kim JY, Kwon JH, Ahn SH, Il LS, Han YS, Choi YO, et al. Effect of probiotic mix (Bifidobacterium bifidum, Bifidobacterium lactis, Lactobacillus acidophilus) in the primary prevention of eczema: A double-blind, randomized, placebo-controlled trial. Pediatr Allergy Immunol. 2010 Mar;21(2 Pt 2):e386-93.

70 Yassour M, Vatanen T, Siljander H, Hämäläinen AM, Härkönen T, Ryhänen SJ, et al. Natural history of the infant gut microbiome and impact of antibiotic treatment on bacterial strain diversity and stability. Sci Transl Med. 2016 Jun 15;8(343):343ra81.

71 Björkstén B, Sepp E, Julge K, Voor T, Mikelsaar M. Allergy development and the intestinal microflora during the first year of life. J Allergy Clin Immunol. 2001;108(4):516-20. .

72 Mah KW, Björkstén B, Lee BW, van BHP, Shek LP, Tan TN, et al. Distinct pattern of commensal gut microbiota in toddlers with eczema. Int Arch Allergy Immunol. 2006 May;140(2):157-63.

73 Dashraath P, Wong JL, Lim MX, Lim LM, Li S, Biswas A, et al. Coronavirus disease 2019 (COVID-19) pandemic and pregnancy. Obstet Anesth Dig. 2021;41(1):7.

74 Mullins E, Evans D, Viner RM, O'Brien P, Morris E. Coronavirus in pregnancy and delivery: rapid review. Ultrasound Obstet Gynecol. 2020;55(5):586-92.
75 Galang RR, Chang K, Strid P, Snead MC, Woodworth KR, House LD, et al. Severe coronavirus infections in pregnancy: A systematic review. Obstet Gynecol. 2020;136(2):262-72.

76 Hantoushzadeh S, Aliabad RA, Norooznezhad AH. Antibiotics, inflammation, and preterm labor: a missed conclusion. J Inflamm Res. 2020;13:245-54.

77 Poon LC, Yang H, Kapur A, Melamed N, Dao B, Divakar H, et al. Global interim guidance on coronavirus disease 2019 (COVID-19) during pregnancy and puerperium from FIGO and allied partners: Information for healthcare professionals. Int J Gynecol Obstet. 2020;149(3):273-86.

78 Wang X, Zhou Z, Zhang J, Zhu F, Tang Y, Shen X. A case of 2019 novel coronavirus in a pregnant woman with preterm delivery. Clin Infect Dis. 2020;71(15):844-6.

79 Hantoushzadeh S, Shamshirsaz AA, Aleyasin A, Seferovic MD, Aski SK, Arian SE, et al. Maternal death due to COVID-19. Am J Obstet Gynecol. 2020;223(1):109.e1-109.e16.

80 Arboleya S, Sánchez B, Solís G, Fernández N, Suárez M, Hernández-Barranco AM, et al. Impact of prematurity and perinatal antibiotics on the developing intestinal microbiota: a functional inference study. Int J Mol Sci. 2016 Apr 29;17(5):649.

81 Kuperman AA, Koren O. Antibiotic use during pregnancy: how bad is it? BMC Med. 2016 Jun 17;14(1):91.

82 Rougé C, Goldenberg O, Ferraris L, Berger B, Rochat F, Legrand A, et al. Investigation of the intestinal microbiota in preterm infants using different methods. Anaerobe. 2010;16(4): 362-70.

83 Brooks B, Firek BA, Miller CS, Sharon I, Thomas BC, Baker R, et al. Microbes in the neonatal intensive care unit resemble those found in the gut of premature infants. Microbiome. 2014 Jan 28;2(1):1.

84 Arboleya S, Binetti A, Salazar N, Fernández N, Solís G, Hernández-Barranco A, et al. Establishment and development of intestinal microbiota in preterm neonates. FEMS Microbiol Ecol. 2012;79(3):763-72.

85 Jacquot A, Neveu D, Aujoulat F, Mercier G, Marchandin H, Jumas-Bilak E, et al. Dynamics and clinical evolution of bacterial gut microflora in extremely premature patients. J Pediatr. 2011;2011(3):109-12.

86 Rajar P, Saugstad OD, Berild D, Dutta A, Greisen $G$, Lausten-Thomsen $U$, et al. Antibiotic stewardship in premature infants: a systematic review. Neonatology. 2020;117(6):673-86.

87 Kuppala VS, Meinzen-Derr J, Morrow AL, Schibler KR. Prolonged initial empirical antibiotic treatment is associated with adverse outcomes in premature infants. J Pediatr. 2011;159(5):720-5.

88 Greenwood C, Morrow AL, Lagomarcino AJ, Altaye M, Taft DH, Yu Z, et al. Early empiric antibiotic use in preterm infants is associated with lower bacterial diversity and higher relative abundance of enterobacter. J Pediatr. 2014;165(1):23-9.
The Effect of COVID-19 Pandemic on Infant's Microbiota
Int Arch Allergy Immunol 2022;183:435-442 DOI: $10.1159 / 000520510$ 
89 Marra F, Lynd L, Coombes M, Richardson K, Legal M, FitzGerald JM, et al. Does antibiotic exposure during infancy lead to development of asthma? A systematic review and metaanalysis. Chest. 2006 Mar;129(3):610-8.

90 Zhao D, Su H, Cheng J, Wang X, Xie M, Li K et al. Prenatal antibiotic use and risk of childhood wheeze/asthma: a meta-analysis. Pediatr Allergy Immunol. 2015;26(8):756-64.

91 Moles L, Manzano S, Fernández L, Montilla A, Corzo N, Ares S, et al. Bacteriological, biochemical, and immunological properties of colostrum and mature milk from mothers of extremely preterm infants. J Pediatr Gastroenterol Nutr. 2015;60(1):120-6.

92 Rodríguez JM. The origin of human milk bacteria: Is there a bacterial entero-mammary pathway during late pregnancy and lactation? Adv Nutr. 2014;5(6):779-84.
93 Kim H, Sitarik AR, Woodcroft K, Johnson CC, Zoratti E, Breastfeeding, et al. Birth mode, breastfeeding, pet exposure, and antibiotic use: associations with the gut microbiome and sensitization in children. Curr Allergy Asthma Rep. 2019 Mar 11;19(4):22.

94 Tun HM, Konya T, Takaro TK, Brook JR, Chari R, Field CJ, et al. Exposure to household furry pets influences the gut microbiota of infants at 3-4 months following various birth scenarios. Microbiome. 2017 Apr 6;5(1):40.

95 Nermes M, Niinivirta K, Nylund L, Laitinen $\mathrm{K}$, Matomäki J, Salminen S, et al. Perinatal pet exposure, faecal microbiota, and wheezy bronchitis: is there a connection? ISRN Allergy. 2013;2013:1-6.

96 Azad MB, Konya T, Maughan H, Guttman DS, Field CJ, Sears MR, et al. Infant gut microbiota and the hygiene hypothesis of allergic disease: impact of household pets and siblings on microbiota composition and diversity. Allergy, Asthma Clin Immunol. 2013 Apr 22;9(1):15.
97 Hesselmar B, Hicke-Roberts A, Lundell AC, Adlerberth I, Rudin A, Saalman R, et al. Petkeeping in early life reduces the risk of allergy in a dose-dependent fashion. PLoS One. 2018 Dec 19;13(12):e0208472.

98 Ho J, Hussain S, Sparagano O. Did the COVID-19 pandemic spark a public interest in pet adoption? Front Vet Sci. 2021;8:647308.

99 CDC. Animals and COVID-19: CDC; 2021 Oct 11. Available from: https://www.cdc. gov/coronavirus/2019-ncov/daily-life-coping/animals.html.

100 Parry NMA. COVID-19 and pets: when pandemic meets panic. Forensic Sci Int Rep. 2020;2:100090. 